\title{
MENELAAH URGENSI PENDIDIKAN BAGI PEREMPUAN SESUAI DENGAN PEMIKIRAN R.A. KARTINI
}

\author{
Indira Syifa Karai Handak ${ }^{1}$, Kuswanto ${ }^{2}$ \\ Pendidikan Guru Sekolah Dasar, Universitas Pendidikan Indonesia \\ Email: indirasyifa@upi.edu
}

Website : https://jurnal.uin-antasari.ac.id/index.php/ptkpend/index

Received: 26 Mei 2021; Accepted: 07 Juni 2021; Published: 14 Juni 2021

\begin{abstract}
This research was conducted to examine in depth the urgency of education for women according to the thoughts of R.A Kartini. This research study uses a descriptive approach. The rationale and discussion results are obtained from the results of literature studies from various sources such as journals, articles and electronic books. It was found that the theory regarding the urgency of education for women is in line with R.A Kartini's thinking which contains 5 aspects according to the book Habis Gelap Terbitlah Terang in achieving the same level of equality with men. By understanding the theory based on R.A Kartini's thoughts, it is hoped that it will be able to increase the urgency of education for women today so that it can run properly.
\end{abstract}

Keywords: Urgency; Women's Emancipation; Education for Women; R.A Kartini.

\begin{abstract}
ABSTRAK
Penelitian ini dilakukan untuk menelaah secara mendalam mengenai urgensi pendidikan bagi perempuan yang sesuai menurut pemikiran R.A Kartini. Kajian penelitian ini menggunakan pendekatan deskriptif. Dasar pemikiran dan hasil pembahasan diperoleh dari hasil studi kepustakaan berbagai sumber seperti jurnal, artikel dan buku elektronik. Diperoleh hasil bahwa teori mengenai urgensi pendidikan bagi perempuan ini selaras dengan pemikiran R.A Kartini yang terdapat 5 aspek sesuai dengan buku Habis Gelap Terbitlah Terang dalam mencapai tingkat kesetaraan yang sama dengan laki-laki. Dengan memahami teori berdasarkan pemikiran R.A Kartini tersebut diharapkan mampu untuk meningkatkan urgensi pendidikan bagi perempuan di masa sekarang agar dapat berjalan dengan semestinya.
\end{abstract}

Kata Kunci: Urgensi, Emansipasi perempuan, Pendidikan bagi Perempuan, R.A. Kartini.

\section{PENDAHULUAN}

Membicarakan mengenai pentingnya suatu pendidikan adalah hal yang sudah tidak asing lagi, Ainiyah (2017) mengatakan hal ini dikarenakan bahwa pendidikan adalah suatu tolak ukur yang digunakan untuk menilai kualitas suatu bangsa. Pendidikan bagi perempuan juga tidak dapat dikesampingkan, seperti R.A. Kartini yang memandang bahwa pendidikan merupakan sesuatu yang harus di perjuangkan dan itu menunjukan bahwa suatu pendidikan sangat dinilai penting bagi perempuan. Yang dapat mengangkat derajat dan martabat suatu bangsa tidak lain dan tidak bukan adalah dengan pendidikan itu sendiri. Pramudawardhani \& Estiana (2019) pun menjelaskan bahwa pendidikan yang dimaksudkan yaitu pendidikan yang dapat diterima oleh semua kalangan, baik dari laki-laki 
ataupun perempuan, maka dapat disebutkan bahwa pendidikan yang dicita-citakan oleh kartini sangat mulia karena ia ingin pendidikan yang mengedepankan budi perkerti yang luhur.

Pendidikan perempuan merupakan suatu proses transfer ilmu kepada perempuan yang tidak menjadi perbedaan antara kaya dan miskin, laki-laki ataupun perempuan, semua memiliki hak yang sama untuk belajar karena, umat islam telah mewajibkan bahwa belajar merupakan kewajiban untuk setiap muslim laki-laki maupun perempuan (AlAbrasyi, Muhammad Athiyah, 1970). Menurut buku hasil penelitian yang ditulis oleh Sadli, (2010) bahwa antara laki-laki maupun perempuan sama sama memiliki potensi yang sama besar, jadi tidak bisa di bedakan bahwa perempuan tidak boleh untuk memperoleh suatu pendidikan, hal ini sudah dibuktikan kebenarannya dalam sebuah studi psikologi tentang taraf intelegensi kesesuaian antara laki-laki dan perempuan. Atas dasar beberapa hal, pendidikan formal ataupun penerapan keahlian tidak kalah dengan laki-laki, bahkan perempuan kerap dinilai lebih baik. Hal ini berarti, pendidikan berlaku bagi semua orang, bukan hanya laki-laki saja tetapi perempuan juga berhak untuk menganyam pendidikan dalam urgensi yang telah dijelaskan oleh Kartini.

Namun, hasil penelitian Muthoifin, dkk (2017) disebutkan bahwa di zaman era Kartini ini, budaya Jawa menanamkan pemikiran bahwa perempuan derajatnya lebih rendah daripada laki-laki, yang mana perempuan tidak diberikan akses kebebasan untuk memanifestasikan dirinya sendiri. Bagi rakyat Jawa tugas dari perempuan hanya untuk memasak didapur dan menyelesaikan pekerjaan rumah saja sehingga tidak perlu untuk belajar ke jenjang pendidikan, sebab lakilaki yang lebih dominan dan diutamakan. Dalam hasil penelitian Fudhailidi (2002) yang mengemukakan pada zaman itu pula terdengar banyak cerita klasik yang beredar di masyarakat bahwa perempuan diciptakan dari tulang rusuk Adam sehingga memberi gambaran kekurangan terhadap perempuan dan keungggulan dari laki-laki. Dari hal diatas, dapat disimpulkan mengenai permasalahannya yaitu pendidikan bagi anak perempuan yang masih kurang merata pada saat itu.

Adapun T. Parson (1998) mengatakan bahwa pada masa Kartini pun kecenderungan membatasi kebebasan perempuan untuk dapat memperoleh pendidikan yang sangat penting ini masih juga berlanjut, ketidaksejajaran antara perempuan dan laki-laki dimunculkan oleh ideologi politik Indonesia, yang penjelasanya berasal akar dari perspektif ideologi fungsionalis yang mengungkapkan bahwa laki-laki dan perempuan mempunyai peran dan dalam lingkup yang berbeda. Berdasarkan uraian diatas, penulis tertarik untuk membahas mengenai pendidikan bagi perempuan yang sesuai dengan pemikiran Kartini, yang didasarkan bahwa R.A Kartini merupakan pelopor pendidikan perempuan yang pertama di Indonesia dan terlebih lagi mengenai gagasan dalam perjuangan untuk memperjuangkan emansipasi perempuan yang sangat menginspirasi. Terakhir, Buya Hamka (2014) menjelaskan bahwa perempuan memiliki hak istimewa yang dibuktikan dengan perempuan dipandang mulia dan tidak lebih rendah dibandingkan laki-laki. Hal ini juga tercantum dalam UndangUndang Republik Indonesia Nomor 7 tahun 1984 tentang validasi konvensi penghapusan segala bentuk diskriminasi terhadap perempuan dan kebijakan untuk mewujudkan keseetaraan gender di Indonesia.

Hal tersebut telah dikupas oleh pemikiran kartini yang menolak adanya diskriminasi gender terhadap pendidikan bagi perempuan, ia ingin melepas belenggu lama adat istiadat dengan mengemban semboyan kebebasan dan keriangan. Karena, urgensi pendidikan perempuan ini sangat penting dimana 
perempuan akan menjadi madrasah pertama bagi anak-anaknya kelak (Ima, dkk : 2020).

\section{METODE PENELITIAN}

Dalam penelitian ini, peneliti menggunakan jenis penelitian kualitatif atau pendekatan secara deskriptif dengan pendekatan yang bersifat studi literatur (kepustakaan) yang berfokus pada jurnal, buku, maupun artikel yang berkaitan dengan R.A Kartini. Data primer penelitian ini adalah menelaah pemikiran R.A Kartini mengenai pendidikan bagi Perempuan pada buku 'Habis Gelap Terbitlah Terang, sedangkan data sekunder meliputi: pemikiran Kartini yang terdapat pada jurnal-jurnal penelitian, biografi ataupun buku-buku lainnya. Analisisnya memakai analisis konten yang membahas secara mendalam dalam konteks ini.

\section{HASIL DAN PEMBAHASAN}

Setelah peneliti melakukan pengkajian dari berbagai sumber, pendidikan bagi perempuan yang sesuai menurut R.A Kartini memang sangat penting untuk diperjuangkan. Hal ini terbukti atas perjuangan emansipasi sesuai pemikiran R.A Kartini yang berpendapat bahwa pendidikan tidak dapat dibedakan hanya karena perbedaan jenis kelamin antara laki-laki dengan perempuan. Karena bagi Kartini, pendidikan bukan hanya tentang ingin meraih keberhasilan semata saja, namun juga sebagai pengabdian tentang budi, jiwa juga akal pikiran yang tertanam. Disini, pemikiran dan juga tekad dalam semangat belajar RA. Kartini selalu berkobar dan tidak pernah padam. Pemikirannya terbagi pada perempuan yang tidak diperbolehkan untuk mengenyam dunia pendidikan, sementara ia ingin semua perempuan dapat memperoleh pendidikan yang sama rata tanpa ada halangan ataupun paksaan untuk menurut pada adat tradisi secara turun temurun.

Seperti yang diketahui, keadaan pendidikan bagi perempuan pada saat itu masih sangat kurang merata, keadaan perempuan pada masa Kartini tidak sebebas perempuan yang berada di masa sekarang. Perempuan pada saat itu masih terkekang dengan adat istiadat lama dan belum ada kemajuan pengajaran dalam suatu bangsa. Ditinjau dari hasil penelitian Ustianingsih (2016:155-156) Sebutan perempuan sebagai "Swargo nunut neroko katut", yang jika diartikan dalam bahasa Indonesia adalah "Surga turut neraka ikut" begitu kental dianut oleh masyarakat Jawa pada masa Kartini, yang berarti jika laki-laki mengarahkan pandangan disitu juga perempuan pergi tanpa ada hak untuk bertanya ataupun menolaknya. Sehingga perempuan hanya dapat melakukan kodratnya yaitu sebagai ibu rumah tangga yang hanya berdiam diri dirumah dan tidak diperbolehkan untuk belajar.

Pada saat Kartini memasuki usia belajar, ia disekolahkan di sekolah rendah yang didirikan oleh Pemerintah Hindia Belanda. Disekolah ini pun ia mendapatkan batasan dan kesulitan akses dari pengajaran, mengalami diskriminasi warna kulit, status sosial dan juga susunan kepegawaian. Guru pun enggan untuk memberi nilai yang tinggi bagi anak pribumi. Disinilah kekecewaan R.A Kartini dimulai sehingga ia bertekad bahwa sekolah yang ingin ia dirikan tidak boleh ada dikriminasi terhadap seseorang. Pendidikan yang dialami oleh Kartini pun hanya berlangsung sampai usia 12 tahun saja, lalu ketika sudah menikah, ia bersama adiknya membuka sekolah khusus bagi anak perempuan, yang memfokuskan pada pembinaan ahlak dan juga karakter pada anak. Meskipun ia tidak bisa melanjutkan pendidikan pada taraf yang lebih tinggi karena tidak mendapat izin dari ayahnya sewaktu muda, namun ia dapat membuka sekolah 
pun turut mengajar anak perempuan di Rembang, Jawa Tengah.

Menilik pada kilas perjalanan hidupnya yang sesuai dengan buku Habis Gelap Terbitlah Terang, Kartini menjadi pelopor pertama bangkitnya pendidikan perempuan di nusantara, Indonesia. Perjuangan emansipasi yang amat luar biasa menjadikan jalan bagi perempuan untuk semangat dalam memperjuangkan haknya mendapatkan pendidikan. Perjuangan yang dimulai ketika ia menulis surat mengenai pemikirannya atas kondisi sosial yang terjadi pada saat itu, terutama terhadap kondisi perempuan pribumi yang sangat memprihatinkan. Yang mana isi dari surat tersebut sebagian besar berisi tentang keluhan pada budaya Jawa yang menghambat kemajuan bagi kaum perempuan. Ia berharap dapat pertolongan dari luar, yaitu teman pena nya yang berada di Eropa. Surat itu dikirim kepada nona Zeehandelar pada tahun 1901 yang disana Kartini menjelaskan bahwa usaha dalam memajukan suatu bangsa adalah wajib untuk saling bersatu dan berhubungan, jadi tidak ada perbedaan antara laki-laki dan perempuan, derajat perempuan pun tidak lebih rendah daripada derajat lakilaki. Ia menepis perbedaan yang membatasi perempuan dalam haknya untuk mendapatkan pendidikan, yang akhirnya lahir beberapa teori berdasar pemikiran R.A Kartini mengenai urgensi pendidikan sesuai dengan buku yang ditulisnya (Kholisoh, S, 2016:48-56), yaitu buku Habis Gelap Terbitlah Terang, yaitu:

1. Perempuan adalah tempat pendidikan paling pertama

Di dalam surat yang ditulis oleh Kartini pada nyonya Abendanon 21 januari 1901, ia mengungkapkan bahwa urgensi pendidikan bagi perempuan adalah sifat yang paling utama, karena dari seorang perempuanlah pendidikan karakter seorang anak itu dapat dibentuk. Perempuan akan menjadi seorang ibu dan memang kodrat dari seorang ibu lah yang memberikan pendidikan pertama sebelum melanjutkan pada taraf pendidikan sekolah. Kutipan mengenai "Ibu adalah madrasah pertama bagi anak" memang nyata adanya dan menjadi patokan mengenai arti dari seluruh kehidupan. Menurut penelitian yang menjelaskan pandangan menurut Kartini ini mengatakan bahwa pendidikan yang lebih dahulu ada adalah pendidikan yang berasal dari rumah, terutama dari seorang ibu (Abdul, 2020:96) Karena, pendidikan tahap awal ini akan membentuk kepribadian anak saat mulai beranjak dewasa. Peran dari seorang ibu sangat kritis menjadi penentu suksesnya pendidikan yang berpengaruh besar dalam kemajuan bangsa. Itulah salah satu alasannya mengapa perempuan harus dan memiliki tingkat urgensi yang tinggi dalam mendapatkan pendidikan, karena kelak perempuan-perempuan ini akan menjadi ibu sekaligus menjadi madrasah yang baik bagi anak-anaknya.

2. Perempuan adalah pembawa peradaban

Kartini berpendapat bahwa kedudukan perempuan yang menjadi pembawa peradaban adalah hal yang sangat penting. Tidaklah maju suatu bangsa tersebut apabila kehidupan kaum perempuan bangsanya masih tertinggal jauh. Sesuai juga dengan tulisannya pada Abendanon ketika Kartini ingin mendirikan sekolah, yang kemudian oleh Abendanon tulisan tersebut disampaikan kepada pemerintah. Maksud dari surat tersebut adalah bahwa perempuanlah yang dapat membolak-balikan suatu kehidupan manusia, karena perempuan dapat membantu untuk mengembangkan kesusilaan manusia tetapi juga dapat menjatuhkan kehidupan kesusilaan manusia itu sendiri. Dari perempuanlah pengaruh yang besar datang dengan maksud baik atau malah bisa jadi buruk. Diketahui melalui surat yang Kartini berikan kepada Tuan dan Nyonya Anton pada tanggal 4 Oktober 1902, ia juga mengatakan akan pentingnya pendidikan 
bagi perempuan untuk memajukan peradaban suatu bangsa. Karena jika urusan dalam memajukan sebuah peradaban dalam suatu bangsa diserahkan pada perempuan yang memang berpendidikan tentulah kemajuan itu akan cepat tergapai. Tentunya, hal ini terjadi dikarenakan perempuan-perempuan yang berpendidikan akan melahirkan generasi yang cerdas dan juga mampu untuk membentuk generasi emas.

3. Prinsip pendidikan bagi perempuan Prinsip pendidikan yang dinginkan oleh Kartini adalah pendidikan yang bukan hanya mementingkan aspek kognitifnya saja, tetapi juga pada aspek psikomotoriknya. Karena tujuan urgensi pendidikan bagi perempuan ini menurutnya ialah untuk menjadikan perempuan sama rata, tidak ditindas atau dihina maupun dikekang dalam kebebasannya. Tujuannya pun untuk menjadikan perempuan sebagai manusia yang mampu untuk bertutur kata dengan baik, yang berbudi pekerti luhur dan juga mampu untuk mengemban kewajiban yang besar dalam kehidupan bermasyarakat. Hal itu diungkapkan Kartini dalam surat kepada nyonya Abendanon yang didalamnya berisi bahwa akan percuma jika manusia itu dikatakan cerdas tetapi tidak memiliki budi pekerti sama sekali. Budi pekerti ini akan menjadikan seseorang memiliki kesusilaan hidup yang baik. Tentunya kecerdasan budi pekerti dan jiwa tidak mungkin dapat terbentuk jika tidak ada perjuangan dan proses yang panjang. Kartini juga mengingatkan bahwa dalam penerapan pendidikan "Janganlah hanya akal saja yang dipertajam, tetapi budi pun juga harus dipertinggi", karena ia menginginkan keseimbangan antara 2 aspek tersebut agar dapat diaplikasikan secara baik tentunya. Selain itu juga, faktor penting dalam pendidikan ini sangat berkorelasi pada kemauan anak didik itu sendiri. Jika tidak ada kemauan, maka usaha tersebut akan sia-sia saja (Malatuny, 2016: 92).
4. Pendidikan dengan kesetaraan antara laki-laki dan perempuan

Afriyanti (2019: 49) mengenai hasil penelitiannya menyebutkan bahwa pendidikan merupakan kunci dari kemajuan suatu bangsa. Kartini berujar bahwa tidaklah pantas jika perbedaan jenis kelamin menjadi batasan untuk pendidikan. Pendidikan menurut Kartini adalah sebuah cara yang dipakai untuk membuka wawasan masyarakat menuju tahap modernitas. Tahapan dalam menuju negara maju, dibutuhkan kesetaraan yang dapat membangun pagar suatu bangsa. Dengan adanya kesetaraan antara lakilaki dan perempuan maka kemajuan suatu bangsa akan lebih mudah dalam pencapaiannya, ini dikarenakan adanya kerjasama di antara keduanya. Adanya persamaan derajat pendidikan disebut sebagai suatu kebebasan bagi kaum perempuan. Tentu kebebasan yang dimaksud adalah kebebasan untuk berdiri sendiri dan menjadi perempuan yang mandiri tidak bergantung pada yang lain. Karena itulah emansipasi perempuan sangat dibutuhkan karena dengan adanya kesetaraan antara laki-laki dan perempuan, maka pemikiran nya akan bersatu dan hasil dari pemikiran tersebut akan melahirkan pemikiran yang lebih baik.

5. Pendidikan sebagai rasa cinta tanah air

Pendidikan cinta tanah air ini merupakan hal yang tidak boleh hilang dalam pemikiran generasi muda, baik laki-laki maupun perempuan. Karena, dengan adanya rasa cinta terhadap tanah air itu juga dapat memajukan peradaban suatu bangsa. Apabila generasi muda yang memiliki kecerdasan akal pikiran tapi tidak memiliki rasa cinta tanah air, dan kecerdasannya hanya digunakan untuk kepentingan diri sendiri saja, pasti pendidikan yang telah dicapainya akan terasa percuma karena tidak ada yang dapat dibagikan pada generasi-generasi selanjutnya. Sebagai contoh, boleh jika ingin mengenyam dunia pendidikan yang 
semakin luas pergi ke negara lain, tapi jangan sampai lupa terhadap negeri sendiri.

Maka dari itu, peneliti mencermati bahwa jika saja pada waktu itu pemikiran adat yang lama diubah menjadi pemikiran yang luas memandang pada masa depan sesuai dengan pemikiran Kartini, tentulah sedari dulu kaum perempuan sudah mendapatkan hak hidupnya. Sejalan dengan pemikiran Abendanon, Kartini memutuskan bahwa pendidikan dianggap sebagai jalur untuk memperoleh pengakuan sejajar dengan kaum laki-laki. Atas kaitan ini, ia diakui sebagai simbol awal gerakan emansipasi perempuan di Indonesia. Gerakan emansipasi yang Kartini galakkan adalah emansipasi kodrati yang berpandangan bahwa perempuan harus mencapai kesetaraan dengan laki-laki dan diposisikan sama dalam segala sesuatu maupun kondisinya. Pendidikan harus menjadi kemajuan bagi siapapun, termasuk hal nya perempuan. Pemikiran Kartini tentang emansipasi yang telah dikemukakan pula menunjukkan bahwa ada kemajuan cara berpikir dan kuatnya keinginannya untuk mencerdaskan masa depan bangsanya, terutama terhadap kaum perempuan. Sebutan kata emansipasi ini sendiri memiliki arti yaitu perjuangan untuk kebebasan. Tafsiran mengenai konsepsi emansipasi perempuan menurut pemikiran R.A kartini termasuk dalam kategori bahasa yang ditinjau dari pemahaman Habermas, karena Kartini menuangkan pemikirannya melalui bahasa yang ia tulis. Kartini memilih untuk menulis sebagai pengganti perjuangannya supaya perempuan terbebas dari kekangan masyarakat Jawa saat itu. Melalui tulisannya, ia bisa menyampaikan keluh kesah, inspirasi serta pemikirannya dan terlebih lagi agar tulisannya diketahui oleh semua masyarakat Jawa agar terlepas dari belenggu adat lama (Mustikawati, 2015:68-70)
Terlebih dari itu, relevansi urgensi pendidikan bagi perempuan yang sesuai pemikiran R.A Kartini juga berpengaruh pada pendidikan yang bersifat humanistik. Humanistik sendiri berarti kemampuan untuk mengarahkan perilaku dalam belajar, sekaligus dapat menjadi motivasi bagi diri sendiri dalam mengenyam pendidikan nantinya. Prinsip pendidikan yang bersifat humanistik ini berasal dari psikologi humanistik, yang kemudian dikembangkan dan akhirnya dikemukakan oleh Abraham Maslow melalui teori hierarki kebutuhan (hierarchy of needs), yang isinya yaitu;

1) Kebutuhan fisiologis (physiological needs) yaitu kebutuhan tubuh secara biologis yang menunjang kehidupan selanjutnya atau bisa disebut dengan kebutuhan dasar.

2) Kebutuhan rasa aman dan nyaman (safety and security) yaitu kebutuhan yang harus ada karena seseorang akan selalu merasa terancam oleh berbagai situasi di lingkungan, ketika kebutuhan dasar sudah terpenuhi, maka otomatis kebutuhan keamanan pun menjadi aktif sendirinya.

3) Kebutuhan akan kasih sayang dan keterikatan (love and belonging) yaitu kebutuhan yang dipenuhi setelah kebutuhan dasar dan rasa aman terpenuhi. Seseorang yang terpuaskan kebutuhan cintanya akan menjadi lebih percaya diri dalam kehidupannya mengenyam pendidikan.

4) Kebutuhan akan harga diri (self esteem), yaitu kebutuhan atas dasar penghargaan dari orang lain dan juga termasuk harga diri. Ketika kebutuhan ini telah tercapai, maka tingkat rasa percaya diri seseorang akan meningkat dan dapat berpengaruh terhadap interaksi sosialnya. 5) Kebutuhan akan aktualisasi diri, yaitu sikap nyata yang mencerminkan keinginan seseorang terhadap diri sendiri, disini seseorang dapat mencapai apa yang ingin dilakukan tanpa batasan atau hambatan apapun. 
Pengembangan potensi ini terfokus pada ciri utama manusia, seperti kemampuan pemenuhan motivasi demi mencapai tujuan pendidikan. Konsep pendidikan menurut pandangan Maslow memberikan tekanan lebih besar pada pengembangan potensi seseorang, terutama potensinya untuk menjadi manusiawi, konsep dalam memanusiakan manusia, memahami diri sendiri dan orang lain, mencapai pemuasan atas kebutuhan-kebutuhan dasar manusia, hingga ke arah pencapaian aktualisasi diri. Teori pendidikan ini akan membantu orang menjadi pribadi yang sebaikbaiknya sesuai kemampuannya. Seperti halnya dengan memanifestasikan nya potensi itu, seseorang mampu menjadi manusia yang sesungguhnya (Fajriyah, 2017: 64-72).

Seiring dengan perubahan zaman, kebudayaan masyarakat perlahan-lahan tentunya berubah. Jika persoalan dahulu seperti yang dipersoalkan oleh Kartini adalah pendidikan bagi perempuan, maka Kartini mungkin akan tersenyum dengan bangga melihat perempuan pada masa sekarang sudah banyak yang bisa mengenyam dunia pendidikan dengan setara. Namun Kartini akan sangat sedih jika yang terjadi malah sebaliknya. Seperti halnya di zaman sekarang, dengan rendahnya tingkat kesadaran yang dimiliki oleh perempuan akan pentingnya mengenyam pendidikan dan juga mengenai cara berpikir sebagian masyarakat yang masih terbelakang, sehingga masih banyak saja yang mengatakan hak perempuan belum ia dapatkan. Oleh karena itu, untuk memperkuat urgensi pendidikan bagi perempuan yang sesuai pemikiran Kartini terhadap kemajuan bangsa di zaman sekarang adalah diharapkan bahwa perempuan tidak lagi mengalami hambatan ataupun tertinggalnya mengenai masalah pendidikan. Sebab pendidikan akan sangat berpengaruh pada kelangsungan kehidupan di masa mendatang, terutama bagi perempuan yang akan menjadi seorang ibu.

Rata-rata kecerdasan seorang anak juga diturunkan dari seorang ibu, maka perempuan yang nantinya akan menjadi seorang ibu haruslah memiliki kecerdasan yang tidak hanya intelektualnya saja tetapi juga memiliki kecerdasan emosional dan spiritual yang baik. Karena, perempuan yang akan menjadi ibu ini akan menjadi inspirasi yang diteladani oleh anak-anaknya kelak, maka perempuan pun butuh bekal pendidikan yang menunjang kecerdasannya tersebut. Tentu, yang dimaksud adalah pendidikan yang bukan hanya sebatas pendidikan formal saja, tetapi juga pengetahuan yang luas dari pengalaman yang pernah dialami. Dan yang terpenting, perempuan harus memiliki kesadaran yang tinggi sehingga dapat mengetahui potensi pendidikan dan memiliki daya saing demi penghidupan masa depan yang lebih baik lagi. Karena dengan kualitas pendidikan yang baik akan dapat menguatkan peran perempuan tersediri dalam kehidupan bermasyarakat dan dapat berkontribusi untuk mengabdi pada agama, bangsa dan negara. Tentunya pemenuhan hak pendidikan bagi perempuan juga harus sejalan karena ini merupakan kewajiban yang diperoleh dari suatu negara. Hal ini yang dimaksud dan di cita-citakan oleh kartini, agar semua perempuan dapat memperoleh hak yang sama dalam pendidikan.

\section{PENUTUP}

Persoalan perempuan memang tidak akan ada habisnya sekalipun sudah seabad lebih Kartini meninggalkan kita semua. Sekarang sudah bukan lagi saatnya untuk melihat Kartini sebagai sosok "Ibu" yang beridentitas kultural Jawa yang melekat dengan sosok dirinya, tetapi yang menjadi urgensi nya adalah bagaimana agar perjuangan emansipasi Kartini dan pemikirannya mengenai urgensi pendidikan bagi perempuan pada saat itu dapat diterapkan sejalan dengan 
keadaan di masa sekarang, dikarenakan perempuan merupakan awal dari tonggak kemajuan peradaban di masa depan. Hasil analisis telaah urgensi pendidikan perempuan yang sesuai dengan pemikiran Kartini pun relevan dengan kajian kali ini. Dilihat dari cara berpikirnya terhadap perempuan sangat berpengaruh terhadap kualitas pendidikan di zaman sekarang. Maka dari itu, sejalan dengan teori yang terdapat lima konsep pemikiran Kartini mengenai urgensi pendidikan bagi perempuan ini telah sesuai. Terlebih dengan pendidikan untuk mencapai kesetaraan derajat sehingga tidak akan ada lagi anggapan yang menganggap bahwa perempuan derajatnya lebih rendah dibandingkan laki-laki. Upaya dalam meningkatkan urgensi pendidikan perempuan dapat dimulai dengan kesadaran dari dalam diri. Dengan adanya kesadaran yang tinggi perempuan dapat mengetahui potensi dirinya demi mengenyam pendidikan yang lebih baik lagi. Juga, adanya teori Maslow mengenai pendidikan yang bersifat humanistik akan mencapai tingkat perkembangan bertahap atas kemampuan sesorang untuk memenuhi kebutuhan dalam mencapai suatu tujuan, yang berhubungan dengan pengaktualisasian diri manusia. Apabila gagasan dan pemikiran kartini dapat direalisasikan dengan baik, diharapkan agar hak perempuan terutama dalam mengenyam pendidikan tidak lagi menjadi permasalahan dan berjalan dengan semestinya sesuai dengan pemikiran R.A Kartini.

\section{DAFTAR PUSTAKA}

Abdul, M. R. (2020). Ibu Sebagai Madrasah Bagi Anaknya: Pemikiran Pendidikan RA Kartini. Journal of Islamic Education Policy, 5(2), 96.

Afriyanti, N. (2019). Kesetaraan Gender dalam Tulisan RA Kartini Perspektif Pendidikan Islam (Doctoral Dissertation, IAIN
BENGKULU). Bengkulu: Institut Agama Islam Negeri (IAIN). Hal 49.

Ainiyah, Q. (2017). Urgensi Pendidikan Perempuan Dalam Menghadapi Masyarakat Modern. Halaqa: Islamic Education Journal, 1(2), 45.

Al-Abrasyi, Muhammad Athiyah. (1970). Dasar-dasar Pokok Pendidikan Islam. Jakarta: Bulan Bintang.

Fajriyah, N. (2017). Female Agency dan Upaya Rekonstruksi Pendidikan Islam: Telaah dan Kontekstualisasi Pemikiran R.A Kartini (Doctoral dissertation, IAIN Salatiga). Tesis Tidak Diterbitkan. Salatiga: Sekolah Pascasarjana Insitut Agama Islam Negeri (IAIN) SALATIGA

Fudhailidi, Ahmad. (2002). Perempuan Lembah Suci: Kritik Atas HaditsHadits Sahih. Yogyakarta: Piar Mdiq.

Hamka. (2014). Buya Hamka Berbicara Tentang Perempuan. Depok: Gema Insani.

Ima, D., Restu, N., \& Yusuf, S. (2020). Nilai-Nilai Pendidikan Karakter RA Kartini dalam Buku Habis Gelap Terbitlah Terang. At-Thullab Jurnal Mahasiswa Studi Islam, 2(1), 347348.

Kholisoh, S. (2016). Konsep Pendidikan Perempuan RA Kartini dalam Buku Habis Gelap Terbitlah Terang (Doctoral dissertation, Fakultas Tarbiyah dan Ilmu Keguruan). Salatiga: Institut Agama Islam Negeri (IAIN). Hal 48-56.

Malatuny, Y. G. (2016). Pemikiran Tokoh-Tokoh Pendidikan Indonesia, Kontribusi serta Implikasi dalam Pendidikan. Jurnal Pedagogika Dan Dinamika Pendidikan, 4(2), 92. 
Mustikawati, C. (2015). Pemahaman emansipasi wanita. Jurnal kajian komunikasi, 3(1), 68-70.

Muthoifin, M., Ali, M., \& Wachidah, N. (2017). Pemikiran Raden Ajeng Kartini tentang Pendidikan Perempuan dan Relevansinya terhadap Pendidikan Islam. Profetika: Jurnal Studi Islam, 18(1), 38.

Pramudawardhani, I., \& Estiana, E. (2019). Perjuangan Dan Pemikiran Ra Kartini Tentang Pendidikan Perempuan. Keraton: Journal of History Education and Culture, 1(1), 41.

Sadli, S. (2010). Berbeda tetapi setara: pemikiran tentang kajian perempuan. Jakarta: Buku Kompas.

T. Parson. (1998). Teori Fungsionalis dalam Bainar, Wacana Wanita dalam Keindonesiaan dan Kemodernan, Yogyakarta: Pustaka Cidesindo, Hal 14-15.

Undang-Undang Republik Indonesia Nomor 7 tentang Pengesahan Konvensi Mengenai Penghapusan Segala Bentuk Diskriminasi Terhadap Wanita. 1984. Jakarta.

Ustianingsih, L. (2016). Kosakata Yang Merepresentasikan Ideologi Perempuan dalam Novel Perempuan Berkalung Sorban Karya Abidah El Khalieqy. Tesis Tidak Diterbitkan. Malang: Sekolah Pascasarjana Universitas Islam Malang 